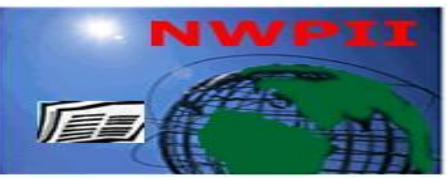

American Journal of Biomedical Sciences

ISSN: 1937-9080

nwpii.com/ajbms

\title{
A GUI (Graphical User Interface) framework to Introduce H-H Model in Comparison with Kv3.3 Model
}

\author{
Taslima Ahmed*, Jiten Ch. Dutta
}

Department of ECE, Tezpur University (a Central University), Napaam Post, Tezpur, Assam, India

*Corresponding Author

Taslima Ahmed

Dept of ECE

Tezpur University

Napaam Post, Tezpur

Assam - 784 028, India

Email: jitend@tezu.ernet.in (Jiten Ch. Dutta), ahmed.taslima@gmail.com (taslima ahmed)

Received: 13 December 2013; | Revised: 10 January 2014; | Accepted: 31 January 2014

\begin{abstract}
The technique of modeling a neuron is mandatory and complex. In this paper, we introduce a simulating window by using graphical user interface (GUI) and it also helps researches in learning Hodgkin-Huxley (HH) complex mathematical equations. By using such type of simulator, users can build any panel for easy analysis and visualization of results. Therefore, here we discuss this type of panel for $\mathrm{H}-\mathrm{H}$ model in comparison with Kv3.3 model that motivates to propose a new version of neuron modeling.
\end{abstract}

Keywords: Neuron; GUI; modeling.

\section{Introduction}

From 1939 to 1952 , Hodgkin-Huxley $(\mathrm{H}-\mathrm{H})$ [1] formulated the existence of ionic current equations across a well developed neuronal circuit by using Kirchhoff's current law. In this paper, we also show the GUI panel for action potential of $\mathrm{H}-\mathrm{H}$ formulation. This $\mathrm{H}-\mathrm{H}$ model was the foundation for describing the neural activity with proper mathematics and further researchers mainly work with it. According to $\mathrm{H}$ $\mathrm{H}$ model, inactivation of $\mathrm{Na}^{+}$ion is purely voltage dependent, and is state independent. But its concept is clearly violated by Kv3.3 model [2] and it verified that the phenomena of inactivation of $\mathrm{Na}^{+}$ion is state dependent rather than voltage dependency. Thus, we are approaching for developing our own model from which researchers can simulate and examine various fundamental concepts of neuron modeling by using GUI as other methods could not give the $100 \%$ accurate solution of $\mathrm{H}-\mathrm{H}$ equations as shown in table1. Building small panel also motivates researchers with the opportunity to solve various types of complexities for synaptic 
modeling. Therefore, it is an appropriate approach for parametric analogy of mathematical equations in one single panel of GUI.

\section{Parametric analogy}

In this paper, we take the values of different parameters of $\mathrm{H}-\mathrm{H}$ and $\mathrm{Kv} 3.3$ models to be plotted in GUI from literature review shown at from table 2 .

From Hodgkin and Huxley model, we are going to conclude the basic equation for current flow due to ionic activity in neurons as

Total ionic current,

Tic $=$ Tnac + Tkc + Tlc eq: 1

Where, $\mathrm{T}=$ total current

ic=ionic current

nac $=$ current flow due to sodium ions

$\mathrm{kc}=$ current flow due to potassium ions

lc $=$ leakage current flow due to chloride ions

According to previous mechanism, the current flow equation can be given by a balanced format as,

Capacity current + Ionic current $=$ Total neuron membrane current

If, Total neuron membrane current=zero, in steady state condition, then

-Capacity current= Ionic current
Again,

Capacity current $=-c D v t$

Ionic current $=$

ina $+i k v 3.3+\mathrm{iklt}+\mathrm{il}+\mathrm{i}_{\mathrm{ext}(t) .}$ eq:3

If eq:2=eq:3, then

$c D v t=\mathrm{ina}+i k v 3.3+\mathrm{iklt}+\mathrm{il}+\mathrm{i}_{\mathrm{ext}(t) .}$ eq:4

Where,

$c=$ capacitace across membrane

$D v t=$ derivative of voltage w.r.t. time

ina $=$ current due to $\mathrm{Na}^{+}$channel

ikv3.3 and iklt = current of Kv3.3 and a Kv1.1like "low threshold" component of voltagedependent $\mathrm{K}^{+}$channel

il = leak current due to other ions

$\operatorname{iext}(t)=$ step currents $(1.0 \mathrm{nA}, 0.25 \mathrm{~ms})$ at 200 $400 \mathrm{~Hz}$

$\mathrm{t}=$ time

Table 1: Different methods for solving H-H equations

\begin{tabular}{|c|c|c|}
\hline Eular method & $50 \%$ & \multirow{5}{*}{$\begin{array}{l}\text { only try to solve the } \\
\text { action potential graph }\end{array}$} \\
\hline Modified Eular method & $60 \%$ & \\
\hline Runga-Kutta & $70 \%$ & \\
\hline Predictor Method & $80 \%$ & \\
\hline MatlabODE45 & $90 \%$ & \\
\hline
\end{tabular}

Table 2 : Comparison of parameters of $\mathrm{H}-\mathrm{H}$ and Kv3.3 model

\begin{tabular}{|l|l|}
\hline H-H Model & Kv3.3 Model \\
\hline Minf $=1 / 1+\exp ((\mathrm{v}-35) /-7.3)$ & Minf $=1 / 1+\exp ((\mathrm{v}-17.81) /-6.95)$ \\
\hline Mtau $=0.678+27.913 /(1+\exp (\mathrm{v}-22.414) / 9.7)$ & M tau $=0.51+9.9 /(1+\exp (\mathrm{v}-17.6) / 12.9)$ \\
\hline Hinf $=0.25+0.75 /(1+\exp ((\mathrm{v}-(-28.294) / 29.385))$ & Hinf $=0.23+0.97 /(1+\exp ((\mathrm{v}-(-27.06) / 36.1))$ \\
\hline Htau $=199.786+(2776.12 * \exp (-\mathrm{v} / 7.3))$ & Htau $=197.98+(3081.46 * \exp (-\mathrm{v} / 7.3))$ \\
\hline
\end{tabular}




\section{Chronicle review of neuron model}

\begin{tabular}{|c|c|c|c|}
\hline Year & Scientist Name & Work/Research/Model & Draw backs \\
\hline 1902 & Bernstein, J. [3] & $\begin{array}{l}\text { Resting potential of a nerve cell is due to } \\
\text { concentration of potassium ions. }\end{array}$ & No existence of sodium ions. \\
\hline 1939 & $\begin{array}{l}\text { Curtis, H. } \\
\text { J.\& Cole, K. S.[4] }\end{array}$ & $\begin{array}{l}\text { Impedance in the nerve cell is due to large drop } \\
\text { in the resistance in parallel with membrane } \\
\text { capacity. }\end{array}$ & $\begin{array}{l}\text { This violated the basic structure of } \\
\text { the membrane. }\end{array}$ \\
\hline 1952 & $\begin{array}{l}\text { Hodgkin, A.L. } \\
\text { and Huxley,A.F. } \\
{[1]}\end{array}$ & $\begin{array}{l}\text { Evolution of an electrical circuit that describes } \\
\text { the existence of both } \mathrm{Na}^{+}, \mathrm{K}^{+}, \mathrm{Cl}^{-} \text {ions. }\end{array}$ & $\begin{array}{l}\text { unable to give accurate } \\
\text { representation of action potential. }\end{array}$ \\
\hline 1960 & Fitzhugh, R. [5] & $\begin{array}{l}\text { Involvement of another variable w instead of } \\
\text { three variable } m, n, h \text {. }\end{array}$ & $\begin{array}{l}\text { not possible to give any circuitry } \\
\text { level for modeling of neuron. }\end{array}$ \\
\hline 1965 & Lewis, E.R [6] & $\begin{array}{l}\text { Locus model for various activities of synaptic, } \\
\text { spontaneous, local potentials, spike initiation. }\end{array}$ & $\begin{array}{l}\text { This model could not give the } \\
\text { mathematical solution for neuron } \\
\text { modeling. }\end{array}$ \\
\hline 1966 & $\begin{array}{l}\text { Harmon, L.D. \& } \\
\text { Lewis, E.R. [7] }\end{array}$ & $\begin{array}{l}\text { Gave the measure like code that reproduces the } \\
\text { details of squid axon membrane conductance. }\end{array}$ & $\begin{array}{l}\text { This circuit was quite complex and } \\
\text { expensive to build. }\end{array}$ \\
\hline 1980 & $\begin{array}{l}\text { Rinzel, J., \& } \\
\text { Miller, R.N. [8] }\end{array}$ & $\begin{array}{l}\text { model describes the dynamics of } \mathrm{H}-\mathrm{H} \text { model } \\
\text { with proper formulation of waveforms. }\end{array}$ & $\begin{array}{l}\text { Output was not in proper spike } \\
\text { format. }\end{array}$ \\
\hline 1981 & $\begin{array}{l}\text { Morris, C. \& } \\
\text { Lecar, H. [9] }\end{array}$ & $\begin{array}{l}\text { Descried the two dimensional system of non- } \\
\text { linear differential equations. }\end{array}$ & $\begin{array}{l}\text { Most of the variables were not } \\
\text { involved. }\end{array}$ \\
\hline 1997 & $\begin{array}{l}\text { Kistler, W.M., et } \\
\text { al. [10] }\end{array}$ & $\begin{array}{l}\text { Four differential equations of } \mathrm{H}-\mathrm{H} \text { model were } \\
\text { reduced by spike generation method. }\end{array}$ & $\begin{array}{l}\text { Limitations were due to threshold } \\
\text { voltage calculation. }\end{array}$ \\
\hline 2000 & $\begin{array}{l}\text { Fukai, H., et al. } \\
\text { [11] }\end{array}$ & $\begin{array}{l}\text { Described an artificial neural network to } \\
\text { identify and model the physiological behavior } \\
\text { with proper threshold value. }\end{array}$ & $\begin{array}{l}\text { This model was very much time } \\
\text { consuming. }\end{array}$ \\
\hline 2002 & $\begin{array}{l}\text { Schaefer, M., et } \\
\text { al. [12] }\end{array}$ & Gave the concept of digital simulation system. & $\begin{array}{l}\text { That required improved modeling } \\
\text { in which rising phase of action } \\
\text { potential can be modified. }\end{array}$ \\
\hline 2006 & $\begin{array}{l}\text { Taylor. J and } \\
\text { Langlois [13] }\end{array}$ & $\begin{array}{l}\text { Developed general purpose circuit analysis } \\
\text { program using PSPICE. }\end{array}$ & $\begin{array}{l}\text { Main problem was that biological } \\
\text { components were not easy to } \\
\text { simulate. }\end{array}$ \\
\hline 2008 & $\begin{array}{l}\text { William, H., et al. } \\
{[14]}\end{array}$ & $\begin{array}{l}\text { Analysis of } \mathrm{H}-\mathrm{H} \text { equations in matlabODE45 } \\
\text { for noise removal. }\end{array}$ & $\begin{array}{l}\text { Biocompatible components were } \\
\text { not to be accurately measured. }\end{array}$ \\
\hline 2010 & $\mathrm{Xu}, \mathrm{J}$. ,et al. [15] & Developed NEUROFET for neuron modeling. & $\begin{array}{l}\text { This was not for synapse } \\
\text { modeling device. }\end{array}$ \\
\hline 2012 & $\begin{array}{l}\text { Vavoulis, D.V.,et } \\
\text { al. [16] }\end{array}$ & $\begin{array}{l}\text { Estimated conductance-based neuron models } \\
\text { traditionally. }\end{array}$ & analyzed result was noisy. \\
\hline
\end{tabular}




\section{Results and Discussion}

We can discuss from the above chronicle review done on modeling of neuron that all models were developed by using different types of software. Due to drawbacks of the different models, we are using GUI for proper verification of inactivation and activation rates of $\mathrm{H}-\mathrm{H}$ and kv3.3 model. Various parameters required to build this model are formulated theoretically and reversal potential of an ion channel along with
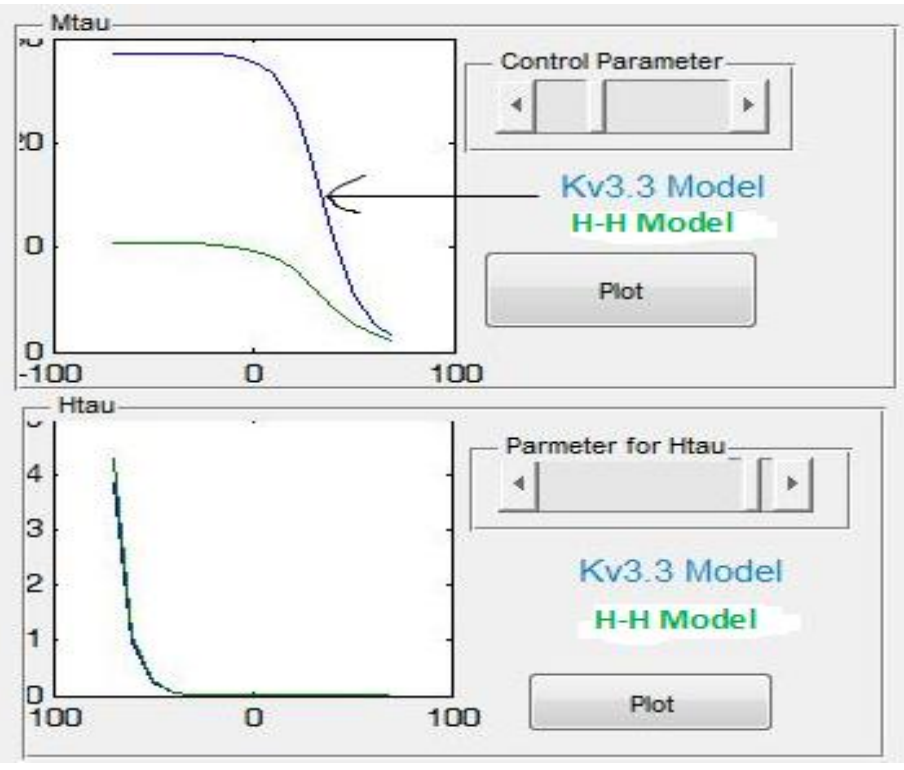

(a) steady state activation and inactivation kinetics are did. Since the equations describing model parameters are often missing from the literature. The digitization process is used to recreate and validate those equations. Figure: 1 below illustrates digitization and plotting of parameters in graphical user interface (GUI) with accuracy and approach to simulate bio components in future.
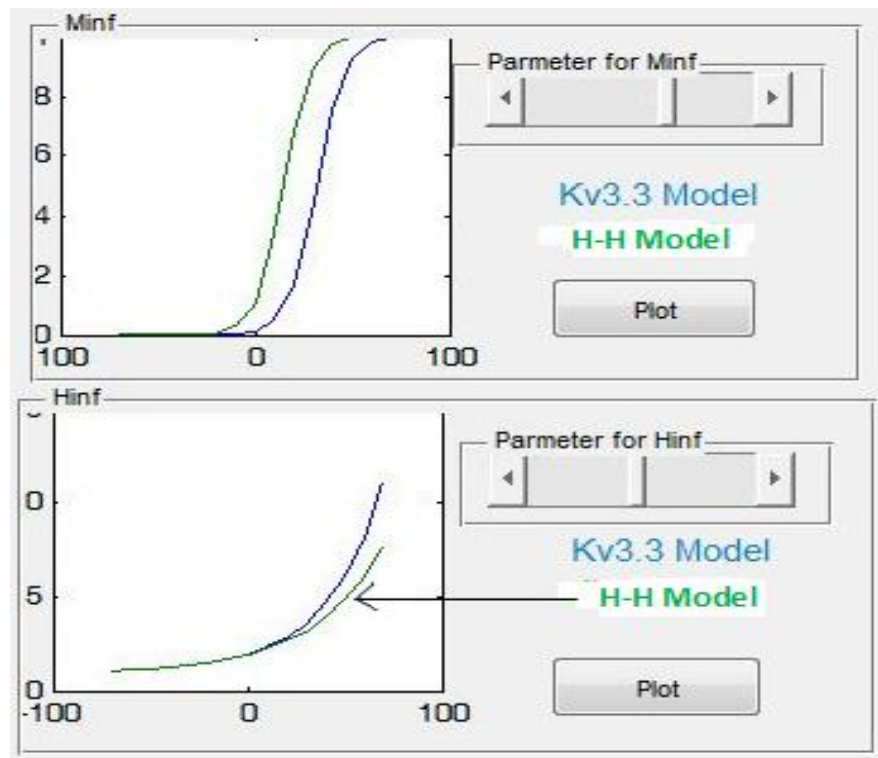

(b)

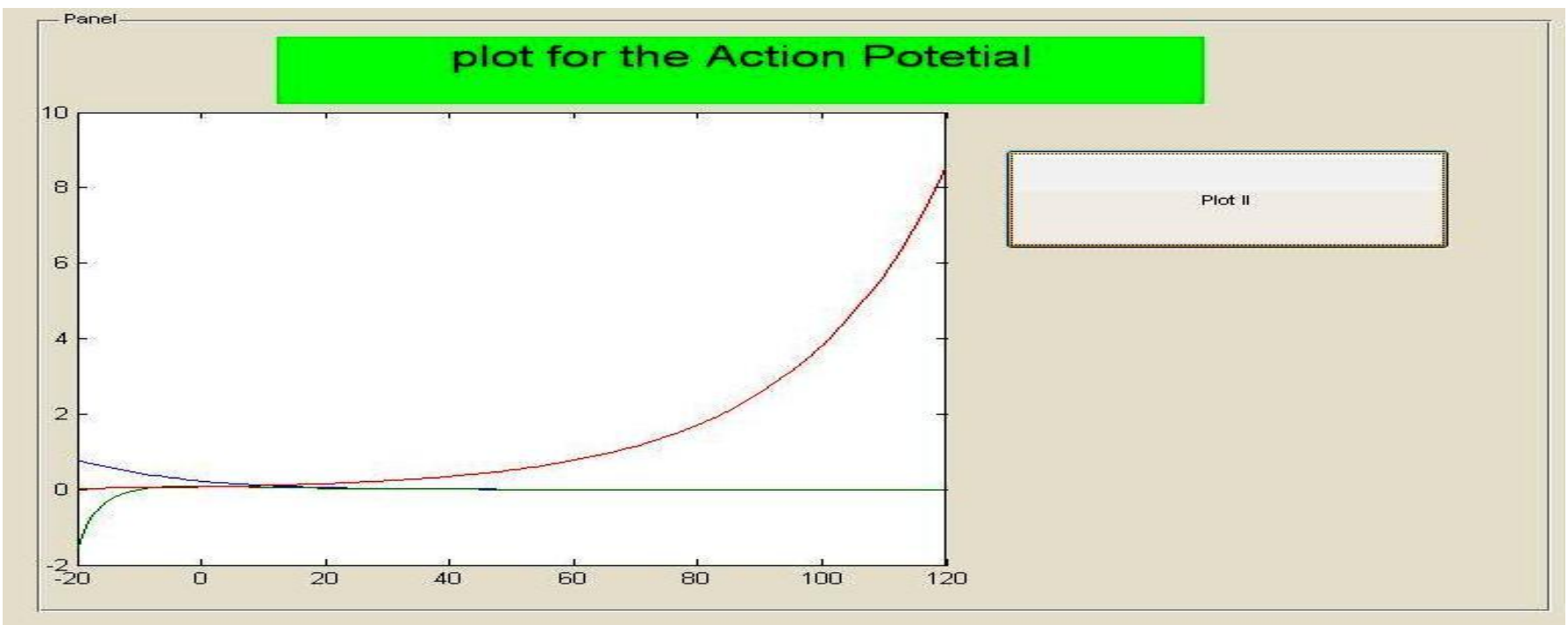

(c)

Figure 1: (a) \& (b) Graph of Mtau, Htau, Minf, , Hinf for kv3.3 \& H-H model and (c) variation of action potential from $\mathrm{H}-\mathrm{H}$ model 
Here, we are mainly discussing the parameters for activation and inactivation rates of $\mathrm{Na}^{+}$(Mtau, Htau, Minf, , Hinf) for Kv3.3 \& H-H models respectively [fig:1 (a) \& (b)] and also variation of action potential graph is shown [fig:1 (c)]. Actually, the model fails to recreate the current traces observed during the experiment. This problem can be solved with proper approximation to the model parameters. Instead of these limitations, we can use this proposed model for biocompatible NEUROFET designing based on this knowledge and verified the state variable concept of the kv3.3 model.

\section{Acknowledgment}

The authors acknowledge the financial support of the UGC towards the development of M.Tech in Bioelectronics under its innovative program scheme at the Department of ECE, Tezpur University.

\section{References}

[1] Hodgkin, A.L. ; Huxley, A.F. A quantitative description of membrane current and its application to conduction and excitation in nerve. J Physiol, 1952, 117(4), 500-44.

[2] Rooma Desai, Jack Kronengold. Protein kinase $\mathrm{C}$ modulates inactivation of $\mathrm{Kv} 3.3$ channels,J. Biol. Chem., 2008, 8 , 283.

[3] Bernstein, J. Studies on the thermodynamics of bioelectric currents, Pflügers Arch. ges. Physiol., 1902, 92, 521-562.

[4] Curtis, H. J., \& Cole, K. S. Membrane and Protoplasm Resistance in the Squid Giant Axon, J. gen. Physiol., 1939, 22 (5), 671687. DOI: $10.1085 / j g p .22 .5 .671$

[5] Fitzhugh, R. Threshold and plateaus in the Hodgkin-Huxley nerve equations, J. gen. Physiol., 1960, 43, 867-896. DOI: 10.1085/jgp.43.5.867

[6] Lewis, E.R. Neuroelectronic potential derived from H-H Model, J. Theoret. Biol., 1965,
10, 125-158. DOI: $10.1016 / 0022-$ 5193(66)90181-0

[7] Harmon, L.D., \& Lewis, E.R. Neural modeling, J. Physiol., 1966, 48, 513-591.

[8] Rinzel, J., \& Miller, R.N. Numerical calculation of stable and unstable periodic solutions to the Hodgkin-Huxley equations, Math Biosci. , 1980, 49, 27-59. DOI: $\underline{10.1016 / 0025-5564(80) 90109-1}$

[9] Morris, C., \& Lecar, H. Voltage Oscillations in the barnacle giant muscle fiber, $J$. Physiol., 1981, 35 (1), 193-213.

[10] Kistler, W.M., et al. Reduction of the Hodgkin-Huxley equations to a singlevariable threshold model. Neural Computation , 1997 9(5), 1015- 1045. DOI: 10.1162/neco.1997.9.5.1015

[11] Fukai, H., et al. Holf bifurcations in multipleparameter space of the HodgkinHuxley equations I: Global organization of bistable periodic solutions, Biological Cybernetics, 2000, 82, 215-222. DOI: 10.1007/s004220050021

[12] Schaefer, M., et al. Simulation of spiking neural networks - architectures and implementations, Neurocomputing, 2002, 48, 647-679. DOI: 10.1016/S09252312(01)00633-6

[13] Masanotti, D., Taylor, J. and Langlois, P. PSPICE models of excitable membranes. In International Conference on Signals and Electronic Systems (ICSES'06), Lodz, Poland, 93-350.

[14] William, H., et al. The Art of Scientific Computing, Cambridge University Press, Cambridge, 2008.

[15] $\mathrm{Xu}, \mathrm{J}$.,et al. Large-signal FET model with multiple time scale dynamics from nonlinear vector network analyzer data, IEEE MTT-S International Microwave Symposium Digest., 2010, 2, 741-744.

[16] Vavoulis, D.V.,et al. A Self-Organizing State-Space-Model Approach for Parameter Estimation in Hodgkin-Huxley-Type Models of Single Neurons, PLOS Comput. Biol., 2012, 8(3). DOI: $\underline{10.1371 / \text { journal.pcbi.1002401 }}$ 